\title{
International Financial Reporting Standards as a tool for Earnings management
}

\author{
Aneta Cugova ${ }^{1, *}$, and Juraj Cug ${ }^{1}$ \\ ${ }^{1}$ University of Zilina, Faculty of Operation and Economics of Transport and Communication, Department of Economics, Univerzitna \\ 8215/1, 01026 Zilina, Slovak Republic
}

\begin{abstract}
.
Research background: The idea of harmonizing accounting at the international level gradually began to spread from the second half of the 20th century as a result of globalization and the growth of international trade. Due to the expansion of this business, users of financial statements have a need for comparability and transparency. National accounting legislation was so different that a reliable assessment of companies from different national backgrounds was not possible. The intention was to create uniform, globally applicable accounting standards.

Purpose of the article: This paper clarifies the theoretical background of selected accounting standards that can significantly expand the scope for earnings management.

Methods: Basic scientific methods of analysis, synthesis, induction, deduction and abstraction were used to meet the stated goal.

Findings \& Value added: The correct application of IFRS can increases the scope for discretionary accounting practices. The change in reporting and valuation according to domestic legislation to reporting and valuation according to international standards may, to varying degrees, affect the picture of the financial position as well as the achieved profit of the company.
\end{abstract}

Keywords: International Financial Reporting Standards; International Accounting Standards; conceptual framework

JEL Classification: CG32; CG30

* Corresponding author: aneta.cugova@fpedas.uniza.sk 


\section{Introduction}

The International Accounting Standards Committee (IASC) was established in 1973 and began issue standards under the designation IAS (International Accounting Standards).

The Committee has been taken over by the International Accounting Standards Board (IASB) and its activities overseen by the International Accounting Standards Foundation (IASCF). The Council has been publishing since 2003 standards called IFRS (International financial reporting standards), while their numbering does not follow the existing IAS - they remain valid until they are replaced by successively issued new IFRS. Today, we consider the set of IAS and IFRS to be international financial reporting standards. [1]

In addition to standards, interpretations are also issued to clarify certain provisions of a particular standard and to ensure a consistent interpretation of the standards. For IAS, they were issued by the SIC (Standards Interpretations Committee), which was later replaced by the IFRIC (International Financial Reporting Interpretation Committee) dealing with the interpretation of newly issued IFRSs. [2]

Within the European Union, accounting and reporting have been regulated since the publication of the Fourth EC Council Directive of 1978 on separate financial statements. Despite the release of others directives, the legislation was not sufficient for the requirements of harmonization, as it contained too much reporting variations. That is why the European Commission presented a new harmonization strategy in 2000, when it chose the already existing IFRS as a tool for accounting regulation in the EU environment. An important step was to require the preparation of consolidated financial statements registered on European stock exchanges in accordance with IFRS, contrary to the previous intention, which the application of IFRS only allowed. An updated version of IFRS is issued annually by the Board for international accounting standards, but for the accounting units of individual Member States are only those standards approved by the Accounting Regulation Committee together with the advisory EFRAG (European Financial Reporting Advisory Group). [3]

Issued IFRS always have the same structure:

- $\quad$ preface - sets the goals of the authorities and the content of their activities,

- conceptual framework,

- $\quad$ standards,

- interpretations,

- $\quad$ semantic dictionary,

- register.

The IAS and IFRS standards themselves are also designed in a certain way and contain:

- definitions of terms used in the standard,

- valuation methods,

- criteria for recognizing items in the financial statements,

- disclosure requirements.

IFRS can be characterized as a principle - based accounting system, which implies that sets out only the requirements for recognizing, measuring and reporting item of the financial statements, but does not specify specific accounting policies.

\subsection{Conceptual Framework}

The introductory part of IFRS is a Conceptual Framework representing the starting point for the standards themselves. It defines the terms that are key to the preparation and presentation of financial statements. It is the theoretical basis of the standards and is important for their understanding. The first version was created in 1989 .

The conceptual framework represents the ideological basis of IFRS. The starting point of the IFRS concept is the analysis of the needs of users of financial information and the formulation of qualitative requirements for the financial statements. The conceptual framework is not a standard and therefore does not define standard solutions for any particular valuation or disclosure issue. The conceptual framework is not a standard, and in the event of a conflict between the wording of a particular standard and the conceptual framework, the standard is followed.

The scope of the Conceptual Framework includes all financial statements, including consolidated ones, and its use is in the public or private sector (commercial, industrial and business enterprises).

The 2018 revised Conceptual Framework sets out:

- the objective of general purpose financial reporting,

- the qualitative characteristics of useful financial information,

- a description of the reporting entity and its boundary,

- definitions of an asset, a liability, equity, income and expenses and guidance supporting these definitions,

- criteria for including assets and liabilities in financial statements (recognition) and guidance on when to remove them (derecognition),

- measurement bases and guidance on when to use them, 
- $\quad$ concepts and guidance on presentation and disclosure,

- $\quad$ concepts relating to capital and capital maintenance.

The conceptual framework allows several ways of valuation of financial statement elements:

- $\quad$ historical cost - represent the amount of cash or cash equivalents required to acquire the asset at the time of purchase; in the case of the liability, it is the amount of revenue that could be received if the liability were transferred,

- $\quad$ current cost - the amount of cash required to purchase a similar asset at present; liabilities will be valued at the undiscounted amount that would have to be settled if the liability were settled at present,

- realizable/settlement cost - the assets are recognized in the balance sheet in the amount of cash or cash equivalents that could be received at present, if the enterprise would dispose of the assets in the normal way (e.g. by sale); liabilities are measured at the level of the undiscounted amount of cash or cash equivalents that the enterprise must pay in the ordinary course of business,

- $\quad$ present value - represents the present discounted value of future net cash inflows that are expected to be generated by the asset in the ordinary course of business; liabilities, on the other hand, are recognized at the present discounted value of future net cash outflows required to settle those liabilities in the ordinary course of business. [4]

However, IFRS 13 - Fair Value Measurement has also entered into force since 2013, the conceptual framework does not describe this valuation option. This standard directly defines the term fair value and is used when another standard permits fair value measurement, even directly requires. Fair value represents the price that could be received at the valuation date sale of an asset, or paid to settle a liability between market participants in the ordinary course of business transactions.

\section{Methodology and data}

The paper deals with the International Financial Reporting Standards themselves, the process of their creation and the content of the conceptual framework. The purpose of this paper is to describe selected standards and to describe and verify the methods of recognition, measurement and reporting of individual elements of financial statements. For the purposes of this article, we have analyzed studies [5 - 10] that result in a specification and description of selected IAS / IFRS standards.

\section{Results}

International accounting systems are similar in many ways. However, there may be significant differences between countries' accounting and these systems. Differences may manifest themselves in the areas of valuation, impairment, or the method of recording the accounting case itself. It can be difficult for accountants to identify these differences, as international systems are often more complex and based on different principles than the home country system. By analyzing the available literature, it was possible to specify and subsequently describe following IAS/IFRS standards.

\subsection{IAS 1 - Presentation of Financial Statements}

The standard sets out the general requirements that an enterprise 's financial statements must meet in order to ensure its comparability over time and with other companies. It can be used individually as well consolidated financial statements, including banks, insurance companies, etc. IAS 1 sets out the definitions of the Conceptual Framework.

A complete set of financial statements comprises:

- a statement of financial position as at the end of the period,

- a statement of profit and loss and other comprehensive income for the period,

- a statement of changes in equity for the period,

- a statement of cash flows for the period,

- notes, comprising a summary of significant accounting policies and other explanatory information,

a statement of financial position as at the beginning of the preceding comparative period when an entity applies an accounting policy retrospectively or makes a retrospective restatement of items in its financial statements, or when it reclassifies items in its financial statements.

The standard also sets out other principles according to which financial statements must be prepared:

Significance and aggregation - significant items are reported separately in the financial statements, which may it is a matter of materiality because of the value of the item or its substance (entity he wants it on a separate line, even if the amount is insignificant; it is mainly informative value for users. If similar items are in insignificant amounts, the enterprise may aggregate them in reports.)

Offsetting - IAS 1 prohibits an entity from offsetting assets and liabilities; revenues and expenses, unless expressly permitted by another standard. For compensation does not consider the creation of provisions and the value of assets less their impairment. Items Gains and losses may be recognized on a net basis if they arise from similar transactions 
(foreign exchange gains and losses, gains and losses on trading in securities); however, if they relate to tangible assets, they are recorded separately in the statements

Reporting frequency - the company is obliged to publish financial statements together with comparative data for the previous period at least once a year. In case he opts for a change in the accounting period and it is therefore necessary to present financial statements for a shorter or longer period, in addition, the reason for this change and the information that the amounts in the financial statements are not completely comparable must be disclosed

Comparative information - the entity must disclose when presenting the financial statements comparative information for the prior period for all items.

Consistency of reporting - it is necessary to maintain consistency in reporting items of financial statement between accounting periods. [11]

\subsection{IFRS 1 - First-time Adoption of International Financial Reporting Standards}

The application of IFRS 1 is possible when the entity starts for the first time report under IFRS instead of current reporting in accordance with national legislation. The standard also applies to interim financial statements prepared in accordance with IAS 34 -Interim financial reporting forming part of the accounting period of the first application of IFRS. Standard requires entities to adopt them when transitioning to international reporting financial statements prepared in accordance with all currently applicable standards.

An entity's first IFRS financial statements and all interim financial statements for part of the period covered by those first IFRS financial statements should include high quality information that is transparent and comparable in all periods presented and provides a good starting point for applying IFRS.

IFRS 1 includes only those financial statements that explicitly declare full compliance with IFRSs and are disclosed also for external users. At the selected date of transition to IFRS reporting is the undertaking is also required to draw up a opening balance sheet, which need not be disclosed. Come "transition date" means the beginning of the earliest period for which the accountant the entity presents complete comparative information in the first IFRS financial statements. At the preparation of the opening balance sheet and the first accounts must be applied to the accounts the rules in force at the date of the first financial statements to which IFRSs apply.

To ensure the possibility of comparing information, it is necessary to make the first financial statements contained three statements of financial position, two statements of comprehensive income, two separate income statement, two statements of cash flows and changes in equity and a commentary containing comparative information.

To comply with IFRS 1, an enterprise adjusts its opening balance sheet as follows:

- include in the balance sheet the assets and liabilities whose recognition is required by the standards,

- does not recognize assets and liabilities whose recognition is not permitted by the standards, reclassifies the assets and liabilities that the enterprise has reported as another type of assets, liabilities or equity items,

- assess assets and liabilities in accordance with standards.

The consequences of the above changes will be shown by the company in the item of previous years retained earnings, or in another item of equity.

All items in the IFRS balance sheet at the beginning of the entity should be reported and measured in accordance with the standards in force at the end of the entity's first IFRS reporting period. These requirements shall be applied retrospectively. It is necessary to recognize all assets and liabilities whose recognition is required by IFRS. Items are not recognized as assets or liabilities unless IFRSs allow such recognition. An entity shall reclassify items that have been recognized as one type of asset, liability or equity item in accordance with previous accounting standards. It is also necessary to apply IFRS in measuring all reported assets and liabilities.

Most of the changes adopted by IFRSs should be dealt with as an adjustment to retained earnings or another appropriate category of equity at the date of transition. Certain assets could be measured at fair value with changes in equity. There are limited circumstances in which adjustments to the IFRS transition are made considering goodwill.

\subsection{IAS 8 - Accounting Policies, Changes in Accounting Estimates and Errors}

IAS 8 applies an entity in selecting and applying accounting policies, where accounting for changes in these rules, when accounting for changes in accounting estimates and also in error correction. In addressing these situations, the standard allows for two options that are used depending on whether it is a change in an accounting policy, an estimate or a correction of an error, namely: retrospective application - the change or correction is made in the period when it arose, i.e. as if she always paid prospective application - the changes are applied in the current period and therefore only apply to future periods.

The objective of the standard is to improve the relevance, reliability and comparability of financial statements. Accounting policies include the specific policies, bases, conventions, rules and procedures that an entity applies in preparing and presenting financial statements. An entity should select its accounting policies in accordance with IFRSs, which are developed and assessed by the IASB based on the Conceptual Framework for Financial Reporting. It should not develop its own accounting policies unless otherwise stated in a particular standard. [12] 


\subsection{IAS 16 - Property, Plant and Equipment}

The objective of the standard is to define the terms related to property, plant and equipment, set out the conditions for recognition in the entity's balance sheet and define the methods of valuation and the recognition of the depreciation of the assets. The scope of the standard includes all land, buildings and equipment other than biological assets (IAS 41) and mineral rights and resources (IFRS 6), which are dealt with in other standards. Some other standards also deal with Tangible Assets, namely IAS 40 Investment Property and IFRS 5 Non-current Assets Held for Sale and Discontinued Operations.

Assets can consist of several different important components. Each component is treated separately and depreciated over its individual useful life. If the life and structure of consumption are similar, the components may be grouped for depreciation purposes. When a significant component is replaced or renewed, the old component is canceled and the new component is capitalized if its price is recoverable.

Entities may use different types of depreciation methods, but they must reflect the economic benefits of the asset used in the enterprise. The most used methods include the linear depreciation method, the performance method, double declining balance method and sum of the year's digits method. The DDB method is based on a constant depreciation rate and a declining depreciation base. The SYD method, on the other hand, is based on a declining depreciation rate and a constant depreciation base. The performance method is based on the principle of the expected performance of an asset (total performance), which represents its applicability.

The depreciation period and method are reviewed at the end of each reporting period and, if there are differences from the originally planned useful life, may be changed in accordance with IAS 8.

\subsection{IFRS 5 - Non-current Assets Held for Sale and Discontinued Operations}

The objective of the standard is to separately allocate assets held for sale to user's statements are made aware of this fact, as it may have an impact on their decision-making. An entity shall classify a non-current asset as held for sale to reimburse its carrying amount for sale rather than future use. Such the asset must be available and ready for immediate sale in its present condition and at the same time the sale must be highly probable - the company's management decides to sell the asset and an active buyer search is underway with a view to making the sale. The price of the asset should be determined by reference to its fair value and the probable completion of the sale be made within one year of the classification of the asset as held for sale.

\subsection{IAS 2 - Inventories}

The standard is used to define inventories, to define their valuation and to publish them in the financial statements. IAS 2 characterizes the concept of inventories as assets: held by the enterprise for the purpose of sale in the ordinary course of business, intended for sale in the production process, in the form of materials and similar supplies consumed in the production process. In accordance with IFRS, it is important to allocate significant spare parts from inventories that are due to other reasons liquidity and the nature of the use by the entity are reclassified to property, plant and equipment assets and are therefore subject to IAS 16.

The standard does not deal with financial instruments that are within the scope of IAS 32 and IFRS 9, as well as biological assets used in agricultural production covered by IAS 41. The standard does not apply to the measurement of inventories of agricultural and forestry products, minerals and agricultural production when valued by net realizable value. Net realizable value is the estimated selling price in the ordinary course of business, less the estimated costs of completion and the estimated costs necessary to make the sale.

IAS 2 provides guidance on determining the cost of inventories and subsequently recognizing costs, including any impairment to net realizable value. It also provides guidance on the cost formulas that are used to assign costs to inventories. Inventories are valued at the lower of cost and net realizable value.

Inventory costs include all purchase costs, conversion costs (direct labor and production overheads) and other costs incurred in bringing inventories to their present condition. Inventory costs are allocated according to the specific identification of costs for inventory items that are not normally exchangeable and are valued individually or using the FIFO method and the weighted arithmetic average. The FIFO (First-In, First-Out) method or weighted arithmetic average is used for items that are normally interchangeable, which generally means large amounts of individual insignificant items. The LIFO (Last-In, First-Out) method was banned in 2003.

When inventories are sold, the carrying amount of those inventories is recognized as an expense in the period in which the related revenue is recognized. The amount of any impairment of inventories to net realizable value and any loss of inventories is recognized as an expense in the period in which the impairment or loss occurs. 


\subsection{IAS 17 -Leases}

The purpose of IAS 17 is to define finance and operating leases and to determine the relevant accounting policies rules for capturing leases for both the lessee and the lessor. It differs significantly from the Slovak legislation, which in the case of a lease prefers the legal form of contracts to the content, which leads to the accounting of the property by the lessor, while the lessee charges only accrued payments According to the standard, however, in the classification of leasing takes into account the substance of the contract before its form. In connection with operating leases, the standard complies with the provisions of Slovak accounting, which implies the importance of differentiation leasing for operational or financial. The standard applies to all leases except those which are dealt with in other standards (IAS 40, IAS 41, leases for the purpose of extracting minerals, raw materials, etc.

\subsection{IAS 20 - Accounting for Government Grants and Disclosure of Government Assistance}

The purpose of IAS 20 is to regulate the accounting and disclosure of government grants and other forms state aid, with the exception of State aid granted in the form of concessions and advantages in determining the taxable income of the entity and government subsidies provided in agriculture, which is devoted in IAS 41 Agriculture.

International Accounting Standards define the state in a broader sense, namely government, government agencies or similar authorities operating in regional, national or international level. The standard recognizes two types of subsidies subsidies to cover costs and subsidies related to assets. The subsidy to cover costs is a grant that is not related to the acquisition of assets and can be reported either as revenues or as a reduction in related costs. It is always necessary to allocate the effect of the subsidy to revenue or expense items.

\subsection{IAS 37 - Provisions, Contingent Liabilities and Contingent Assets}

The standard is used in the recognition, measurement and recognition of provisions, contingent liabilities and assets except for certain transactions arising from financial instruments at fair value; failed contracts and emerging insurance contracts addressed by other standards. The provision represents a liability of an enterprise with an indefinite schedule and amount and an enterprise reported in the balance sheet if there is a current contractual or non - contractual (the enterprise gives its proceedings to show that it is committed to a particular act) the liability of the enterprise which is the result past events. Based on these events, the company has no option to avoid the obligation. The entity must be able to estimate the amount of the liability.

\subsection{IAS 12 - Income Taxes}

IAS 12 deals with accounting policies and procedures about current and deferred tax. The tax due arises from taxable profit, or losses and it is the amount of tax from the profit to be paid / claimed for the given period. Current tax for the current and previous periods the enterprise accounts as a liability. The standards themselves do not address the calculation of income tax, because they are not tax-efficient and therefore depends on the specific national regulation. Deferred tax is only of an informative nature in the balance sheet, but it serves the users of the financial statements, who can assess whether the company will be liable to tax in the future or a right to a reduction in tax due. The company accounts for deferred tax only as at the balance sheet date, therefore not during the accounting period. [13]

\section{Discussion}

It has been found that the quality of reporting is different across nations with different levels of investors protection. [14, 15] Even though the IFRS adoption eliminates the difference in national accounting practices among the adopted countries, earnings management stays unlike across the. It occurs mostly for the divergence in legal system, culture and other practices, which lead to different interpretation and compliance level across countries, as cause of less comparability of the financial statements. Studies suggested that the quality of accounting is higher in strong enforcement countries compare to the weak enforcement countries. [16] Research about IFRS has carried on different problems, such as reaction of the event firms on IFRS adoption, effect of IFRS adoption on the cost of equity, comparability of the firms or financial performance, quality of accounting information, pre and post effect of IFRS adoption on the level of integration, adoption and implementation process of IFRS, cultural effect on the implementation process, etc. Most of the research papers confirm that the key factor of IFRS adoption is to construct a better way for the transparency in financial reporting and the improvement of its quality. [17-19] 


\section{Conclusion}

The manner in which the individual items of the financial statements are accounted for has an important effect on the assessment of the financial position and performance of the company. For example, the chosen valuation method has a significant effect on the total amount of its assets and liabilities. The chosen method of depreciation of assets, on the other hand, affects the amount of its costs, which in turn affect the size of its economic result and performance. The performance of a company may be understood differently from the point of view of different users of financial information, but in general it is a certain prosperity and growth of the value of the company and the ability to ensure its continuity in the future. It is clear from the above that if the accounting methods used by the company change, such a fact will affect the results of the financial analysis. This change may occur, for example, when a company begins to report in accordance with International Financial Reporting Standards (IFRS1), either because of a legal obligation or voluntarily, e.g. due to efforts to increase transparency towards foreign trading partners. As IFRS is gradually being implemented into national accounting legislation, some similarities can be noted in this regard. Over time, there should be a deeper link between IFRS and national legislation through global accounting harmonization.

This research was financially supported by the Ministry of Education, Science, Research and Sport of the Slovak Republic and Slovak Academy of Sciences VEGA 1/0121/20: Research of transfer pricing system as a tool to measure the performance of national and multinational companies in the context of earnings management in conditions of the Slovak Republic and V4 countries.

\section{References}

1. Sramkova, A., Janouskova, M. (2008). IAS/IFRS: mezinarodni standardy ucetniho vykaznictvi: prakticke aplikace. Praha: Institut Svazu ucetnich.

2. Wiley IFRS. (2017). Interpretation and Application of International Financial Reporting Standards. Chichester: Wiley.

3. Dvorakova, D. (2014). Financni ucetnictvi a vykaznictvi podle mezinarodnich standardu IFRS. 4. edice. Brno: BizBooks.

4. Kramarova, K., Valaskova, K. (2020). Application of Chosen Fraudulent Detection Technique in the Slovak Business Environment. SHS Web of Conferences, 74(6), 01019.

5. IFRS (2018). Conceptual Framework for Financial Reporting. IFRS Foundation. https://www.ifrs.org/issuedstandards/list-of-standards/conceptualframework/

6. Jilek, J., Svobodova, J. (2013). Ucetnictvi podle mezinarodnich standardu ucetniho vykaznictvi. Praha: Grada Publishing.

7. Svabova, L., Valaskova, K., Durana, P., Kliestik, T. (2020). Dependency Analysis Between Various Profit Measures and Corporate Total Assets for Visegrad Group's Business Entities. Organizacija, 53(1), 80-90.

8. Khanh, M.T.H, Thu, P.A. (2019). The effect of financial leverage on real and accrual-based earnings management in Vietnamese firms. Economics and Sociology, 12(4), 299-312.

9. Kliestik, T., Valaskova, K., Nica, E., Kovacova, M., Lazaroiu, G. (2020). Advanced methods of earnings management: monotonic trends and change-points under spotlight in the Visegrad countries. Oeconomia Copernicana, 11(2), 371-400.

10. Lyakina, M., Sheehy, M., Podhorska, I. (2019). Networked and Integrated Urban Technologies in Internet of Things-enabled Smart Sustainable Cities. Geopolitics, History and International Relations, 11(2), $62-68$.

11. Sumiyana, S. (2020). Different characteristics of the aggregate of accounting earnings between developed and developing countries: Evidence for predicting future GDP. Journal of international studies, 13(1).

12. Lyakina, M., Heaphy, W., Konecny, V., Kliestik, T. (2019). Algorithmic Governance and Technological Guidance of Connected and Autonomous Vehicle Use: Regulatory Policies, Traffic Liability Rules, and Ethical Dilemmas. Contemporary Readings in Law and Social Justice, 11(2), 15-21.

13. Raisova, M., Regasková, M., Lazanyi, K. (2020). The financial transaction tax: an ANOVA assessment of selected EU countries. Equilibrium. Quarterly Journal of Economics and Economic Policy, 15(1), 29-48.

14. Ball, R., Kothari, S. Robin, A. (2000). The Effect of International Institutional Factors on Properties of Accounting Earnings. Journal of Accounting and Economics, 30(2), 241.

15. Leuz, C., Nanda, D. dan Wysocki, P.D. (2003). Earnings Management and Investor Protection: an International Comparison. Journal of Financial Economics, 69, 505-527.

16. Daske, H. dan Gebhardt, G. (2006). International Financial Reporting Standards and Experts Perceptions of Disclosure Quality. Abacus, 42(3-4), 461-498. 
17. Ebaid, I.E. (2016). International accounting standards and accounting quality in code-law countries The case of Egypt. Journal of Financial Regulation and Compliance, 24(1), 41-59.

18. Blazek, R., Durana, P., Valaskova, K. (2020). Creative accounting as an apparatus for reporting profits in agribusiness. Journal of Risk and Financial Management, 13(11), 261.

19. Guermazi. W., Khamoussi, H. (2018). Mandatory IFRS adoption in Europe: effect on the conservative financial reporting. Journal of Financial Reporting and Accounting, 16(4), 543-563. 